\title{
Acı Hayat (1962) ve Kırık Hayatlar (1965) Filmleri Çerçevesinde Kadının Toplumsal Cinsiyet Kimliğinin İnşası
}

\author{
Dr. Öğr. Üyesi Emrah DOĞAN \\ Bitlis Eren Üniversitesi \\ GSF, Sinema ve Televizyon Bölümü \\ edogan@beu.edu.tr \\ ORCID: 0000-0002-3808-1067
}

\begin{abstract}
Öz
Herhangi bir toplumdaki sosyal ilişkiler, insan bedeninin cinsiyet kimliğini şekillendirir. Ve bu toplumdaki bedenler arasındaki cinsiyet kimliği farkları toplumsal ilişkiler tarafından adlandııımaktadır. Patriarkal toplumda da kadının toplumsal cinsiyet kimliği inşası erilin tahakkümü çerçevesinde belirlenmektedir. Diğer bir ifadeyle erilin hâkim olduğu habitusun kuralları kadının toplumdaki cinsiyet rolünün sınırlarını çizer. Eril iktidar sahip olduğu ideolojik aygıtlar ile de kadının toplumdaki cinsiyet rolünü pekiştirmektedir. Sinema bir sanat olmakla birlikte önemli bir ideolojik aygıtıı. Bu ideolojik aygıt filmler aracıığı ile erilin habitus kurallarını benimsetmeye çalışır. Bizler ise filmleri çözümleyerek eril tahakkümün kadının toplumsal cinsiyet kimliğini nasıl inşa ettiğini irdeleyebiliriz. Türk sinemasında da hem toplumcu gerçekçi filmlerde, hem de popüler melodram filmlerde kadının toplumsal cinsiyetinin nasıl konumlandığını inceleyebiliriz. Bu çalışmanın temel amacı ise 1960'lı yıllarda melodram ağırlıkı filmlerde kadının cinsiyetinin nasıl inşa edildiğini çözümlemektir. 1960'।ı Türk sinemasında rastgele seçile iki örnek ile inceleme yapılmıştır. Bu örneklerden ilki Metin Erksan'ın toplumcu gerçekçi filmlerinden biri olan Acı Hayat filmidir. Diğeri ise Halit Refiğ'in melodram ağırlıklı Kırık Hayatlar filmidir. Bu iki film de teorik çerçeve ışı̆̆ında eleştirel niteliksel film analiziyle incelenmiştir.
\end{abstract}

Anahtar Kelimeler: toplumsal cinsiyet, melodram, türk sineması 


\title{
arts
}

\section{Building the Gender Identity of Women within the Framework of Acl Hayat (1962) and Kırık Hayatlar (1965) Films}

\begin{abstract}
Social relationships in any society shape the sexuality of the human body. And sexual differences between bodies in this society are called by social relationships. In the patriarchal society, the construction of women's sexuality is determined within the framework of masculinity. In other words, the rules of habitus dominated by the masculine draw the limits of the gender role of women in society. The male power reinforces the gender role of women in society with the ideological devices it possesses. Cinema is an art, but an important ideological device. This ideological device tries to adopt the habitus rules of the male through films. We can analyze how masculine domination builds the sexuality of the woman by analyzing the films. In Turkish cinema, we can examine how the gender of women is positioned in both socialist realistic films and popular melodrama films. The main purpose of this study is to analyze how the gender of women was built in movies based on melodrama in the 1960s. In the 1960 Turkish cinema, two randomly selected samples were examined. The first of these examples is $\mathrm{ACl}$ Hayat film, one of Metin Erksan's socialist realistic films. The other one is Halit Refiğ's melodrama based Kırık Hayatlar movie. Both films were analyzed in light of the theoretical framework with critical qualitative film analysis.
\end{abstract}

Keywords: gender, melodrama, turkish cinema 


\section{$\operatorname{arts}=$}

\section{Gíiş̧}

Sinema, insanın kendini, doğayı, geçmişi, şimdiyi, geleceği, arzularını, ütopyalarını teknolojinin imkânlarını ve farklı anlatı kalıplarını kullanarak anlatan bir sanat olmanın yanı sıra, aynı zamanda ideolojik bir aygıt, içinde bulunduğu zaman diliminin toplumsal bir çıktısı ve tüketilen popüler bir eğlence ürünüdür. Bu çalışmanın temel konusu sinemanın sanatsal yanından ziyade, sinema endüstrisinin eğlence ürünü olan melodram filmlerdir.

Eril iktidarın egemen olduğu ve denetlediği sektördeki melodram filmler, elbette ki kadın-erkek arasındaki ilişkileri cinsiyetçi bir şekilde ataerkil yaşamın kuralları çerçevesinde perdeye yansıtmaktadır. Türk sinemasında belli bir dönemde çekilen melodram ağırlıklı popüler filmlerde bu cinsiyetçi yaklaşımı görmek mümkündür. Özellikle Türk sinemasında 1960'lı yıllarda çekilen melodram ağırıklı filmlerde cinsiyetçi bir söylem kullanılarak hem kadın bir arzu nesnesi haline getirilmiş, hem de cinsellik sömürülmüştür. Aynı zamanda bu filmlerde ataerkil kurallar çerçevesinde kadının toplumsal cinsiyet kimliği de inşa edilmiştir. Ataerkil toplum yapısında kadın bir arzu nesnesidir ve kadının toplumsal cinsiyet kimliği de bunun bir parçasıdır. Bunu Türk sinemasındaki melodram filmleri incelemeden önce Türk sineması yazarı Agâh Özgüç'ün Türk Sinemasında Cinselliğin Tarihi kitabının yayınlanma serüveninden anlayabiliriz. Özgüç, hazırladığı çalışmasında Türk sinemasında hem kadının konumunu, hem de cinsel sömürünün nasıl yapıldığını anlatmak istemiş ancak kitabın yayınlanma serüvenine baktığımızda onun amaçları ile yayınevlerinin eril yayın politikaları örtüşmemiştir. Özgüç'ün temas kurduğu yayınevlerinden biri "Türk Sinemasında Cinselliğin Tarihi" yerine Yerli Sinemada Seks ve daha sonra diğer bir yayınevi de Türk Sinemasında Seks (Fotoğraflarla) başlığı adı altında farklızamanlarda iki kitap basılıp yayınlanmıştır (Özgüç, 1994, s. 7-8). Bu kitabın yayınlanma serüveni bize, ataerkil toplum yapısına sahip olan Türk toplumunda cinselliğin ya da cinsellik algııının seks ve arzu nesnesi olan kadın üzerine inşa edildiğini göstermektedir. Ancak bu çalışmanın ana ekseni melodram filmlerde kadının ve toplumsal cinsiyet kimliğinin nasıl perdeye yansıtıldığı olması nedeniyle, 1960'lı yılarda çekilmiş Metin Erksan'ın Acı Hayat-1962 ve Halit Refiğ'in Kırık Hayatlar-1965 filmleri incelenecektir. 


\section{YÖNTEM}

\section{Araştırmanın Amacı}

Bu çalışmanın temel amacı, Türk sinemasının melodram ağırlıklı filmlerinde kadın ve toplumsal cinsiyet kimliğinin sektöre egemen olan ataerkil yapının perdeye nasıl yansıttığı ile kadın ve toplumsal cinsiyet kimliğinin hangi kalıplar üzerine inşa edildiğini irdelemektir.

\section{Araştırmanın Yöntemi}

Türk sinema endüstrisinin 1960'lı yıllarda çekilen melodram ağırlıklı filmlerindeki kadın ve toplumsal cinsiyet kimliği inşası niteliksel eleştirel film analizi yöntemiyle değerlendirilmiştir.

\section{Araştırmanın Evreni ve Örneklemi}

Araş̧ırmanın evreni 1960'lı yıllarda çekilmiş melodram ağırlıklı filmlerdir. Örneklemi ise, bahsi geçen dönem aralığında Türk sinema endüstrisinde film enflasyonunun yoğun olduğu dikkate alınarak, toplum tarafından beğenilmiş olan filmlerdir. Bu filmlerin seçiminde rastgele örneklem kullanılmıştır.

\section{Araştırmanın Sınırlılıkları}

Bu araştırmanın temel sınırlılığı, Türk sinemasında kadın ve toplumsal cinsiyet kimliği algısını anlatan eleştirel bir tarih çalışmasının olmamasıdır. Bir diğer önemli sınırılık ise, 1960'।ı yıllarda melodram ağırlıklı birçok film vardır ancak toplum tarafından beğenilen bu filmler birçoğuna izlemek için ulaşılamamasıdır. 


\section{TEORIK ÇERÇEVE: PATRIARKAL TOPLUMLARDA KADININ TOPLUMSAL CINSIYYT KIMLIĞININ INŞASI}

Toplumsal cinsiyet, cinsler arasındaki eşitsiz ilişkilerin toplumsal bağlamlarına ve anlamlarına dikkat çekerek, cinsiyetin biyolojik bir özellik olarak algılanmasını reddeder (Sancar, 2009, s. 176). Bununla birlikte, toplumsal cinsiyet toplumsal ilişkileri tanımlamaz. Toplumsal ilişkiler insan bedeninin cinselliğini şekillendirir ve bedenler arasındaki cinsiyet farkları cinsellikle ilgili değildir; toplumsal olanın cinsellik üzerinden anlamlandırıması ile ilgilidir (Sancar, 2009, s. 178).

Cinsiyetin biyolojik ve toplumsal özellikleri arasındaki ilişkilere ve bireylerin bunları nasıl kabullendiğine ilişkin üç farklı teorik yaklaşım vardır. Birinci teorik yaklaşım, biyolojik cinsiyetin belirleyiciliğini kabul eden bunun toplumlarda belli bir düzeni gerekli kıldığını söyleyen "biyolojik determinist" olarak tanımlanan yaklaşımlar; ikinci teorik yaklaşım "toplumsal inşa" yaklaşımıdır ve biyolojik cinsiyet-toplumsal cinsiyet ayrımından hareket ederek bu farkların anlamını ve nasıl inşa edildiklerini açıklar. Üçüncü teorik yaklaşım ise, "yapıbozumcu"dur ve temelde biyolojik kökenlik kavramsallaştırmayı bir kenara atarak bütünleşik gerçekliğe gönderme yapan "toplumsal cinsiyet" kavramını kullanır. Bu teorik yaklaşım toplumsal cinsiyet özelliklerini belirlediğini öne sürülen maddi temel ve onun etrafında belirlenen kültürel ve ideolojik ilişkileri ortadan kaldırmaya çalışır. Daha açık bir ifadeyle, biyolojik bedenin bir söylem nesnesi olarak cinsiyet söylemi etrafında kurulduğunu ve anatomik beden tanımının kültürün içinde üretilmiş bir "söylem nesnesi" olduğunu ileri sürer. İnsanlar kendi bedenlerini "anatomi tarafından belirlenmiş sabit" olarak temsil etmeyi seçerler. Ancak cinsiyetlenmiş bedenler biyolojik doğa parçaları değil, toplumsal cinsiyet ilişkilerinin inşa ettiği sosyal alanlar ve mekânlar olarak var olurlar (Sancar, 2009, s. 180-183). Sözün kısası, cinsiyet rolleri toplumdan bağımsız değildir.

Toplumsal cinsiyet ya da toplumsal cinsiyet rolleri Bourdieu'ya göre, cinsellik tarafından oluşturulan bir habitustur (2001, s. 3). Başka ifadeyle, bedensel deneyimlerimiz içinde bulunduğumuz sosyo-kültürel ortamdan bağımsız değildir ve bundan dolayı iç dünyamız ile dış dünyamız arasındaki kesişen noktaları ve sınırları içinde bulunduğumuz sosyo-kültürel ortam belirler (Özbudun, 2015, s. 75). Bir diğer ifadeyle toplumsal olgular ya da dizgeler insanın hem fiziksel, hem de duygusal özelliklerine aracılık ederler (Giddens, 1999, s. 82). Aynı zamanda cinsiyet rolleri gibi 
cinsellik algısı ve cinsel kimlik de yapay bir olgudur. Sosyal inşa sürecinde ortaya çıkan cinsel kimlik, akrabalık ve aile sistemleri, ekonomik ve toplumsal düzen, siyasi ve dinsel müdahaleler sonucunda şekillenmektedir (Weeks, 2016, s. 33).

Bourdieu'nun "habitus" olarak tanımladığı toplumsal cinsiyet kendilerini üreten ve yeniden üreten bu yapılardan ayrılamaz ve burada kadınlar nesneler olarak, erkeklerin elinde tuttuğu sembolik sermayenin gelişimine ve artmasına yol açan araçlar olarak konumlanırlar. Bu habituslarda kadınlar bu ilişkiler içine, anlamı kendi kontrolü dışında belirlenen sembollerin üretimi dolayımı ile dâhil edilirler. Başka bir ifadeyle, kadınların konumlanışı, akrabalık ve evlilik ilişkilerinin değişim nesneleri olarak, erkeklerin çıkarlarına uygun biçimde gerçekleşir ve bu durum erkeklerin sembolik sermayesini arttıır. Eşit erkek cemaatler arasında kadınların konu edildiği değişimler eril iktidar siyasetinin sembolik araçlarıdır. Örneğin namus bir tür sembolik sermayenin birikimine tekabül eder. Namus bağlamında kadın bedeninin deneyimlediği habitus "başkası için yaratılmış olmak"tır. Bu hükmetme kadın bedeninin gözetimi-gözetlenmesi ile "başkalarının ne diyeceği" söylemi üzerinden gerçekleşir. Bu habitus sisteminde eril tahakküm kadınları, sembolik mallar piyasasının nesneleri olarak kurar ve kadınların bu ilişkiler içinde tutulabilme koşulu ise, bedensel güvensizlik konumunda tutulabilmelerinin sürekliliğine bağlıdır (Sancar, 2009 , s. 192). Özellikle ataerkil toplum yapısına sahip Türkiye gibi toplumlarda bunu gözlemlemek mümkündür. Türkiye'nin bütün toplumsal sınıfarında kadın "ailenin namusu" olarak tanımlanmakta ve kadının "cinsel saflığı" erkeğin şerefi için erkekler tarafından desteklenmektedir (Tahincioğlu, 2011, s. 14).

Ataerkil toplumda kadın bedeni cinsel olarak kurgulanmaktadır. Yani kadının bedenini kullanması cinselliği merkeze alıp oluşturulan habitusun kurallarına göre ikincil konumda, itaatkâr, baştan çıkarıcı, arzu edilen nesne, ayartıcı, kendini beğendirmesi gereken ve bunun için ya da bedensel konumuna göre giyinen, hareket eden, yürüyen, konuşan, davranış ve tutumları sergilemekte ve cinsel pratiklerde bulunmaktadır. Bu anlamda erilin egemen olduğu toplumlarda kadının şiddet ve istismar edilmesi şaşırtıcı değildir (Küntay, 2010, s. 17). Bir başka ifadeyle erkeğin egemen ve kurucu olduğu yapıda, hayatın kendisi ve hayat döngüsü zamansal ve mekânsal olarak erilin egemen kodlarına göre kurulur veya kurgulanır (Türk, 2008, s. 129). Bu toplumsal yapıda ikincil konuma itilen kadın "baştan çıkarma" gibi silahları kullanmaya itilir ancak kadının kullandığı bu silah tam da eril egemen 


\section{arts}

yapının kadından beklediği gibi arzu edilen bir nesneye dönüşmesini sağlar (Bourdieu, 2001, s. 59).

Genel olarak patriarkal ya da eril tahakkümün olduğu toplumlarda kadın, erkeğin cinsel partneri ve erkeğin soyunun devamını sağlayan kişidir (çocukların beslenme, büyütme ve bakım işlevlerini yerine getirmek zorundadır). Ve bu toplumlardaki kadın izdüşümü, evlenip, eş ve anne olmalı, namuslu kadın bedenine sahip olmalı, erkeğin soyunun devamını sağlamalı, başka bir soyun karışmaması için namusunu sakınan ve koruyan olmalıdır (Aylin, 2015, s. 38-40).

\section{SINEMADA VE TÜRK SINEMASINDA KADININ TOPLUMSAL CINSIYET KimLiĞi}

Sinema kendi içinde estetik bir yan barındırmakla birlikte aynı zamanda toplumsal bir çıktıdır. İçinde bulunduğu toplumun "değerleri"ni de perdeye yansıtır. Perdeye yansıtılan toplumsal dizgeler çerçevesinde eril tahakkümün algısı üzerine bir çözümleme yapılabilir. Filmler bizlere herhangi bir durumu yansıtmaktan çok, o durumun tasarlanan belli bir biçimini oluşturmak üzere seçilmiş ve birleştirilmiş temsili öğeler yoluyla bir takım tezler ileri sürer, bunu yaparken seyirciye belli bir konumu ya da bakış açısını da telkin ederler. Biçimsel görenekler de, sinemasal yapaylığa ilişkin işaretleri silip süpürerek bu konumlanmanın içselleştirilmesine katkıda bulunur (Ryan ve Kellner, 1997, s. 18). Bu anlamda sinemada kadının toplumsal cinsiyet kimliğinin nasıl temsil edildiğine baktığımızda, 1920'lerin filmlerinde kadın imgesi artan oranda erotikleştirilmesi söz konusuyken, 1930'ların filmsel anlatılarında çocuğun ruhsal görevlerine dikkat çekilmekte iyi ve mutlu insan yetiştirmede bütün yükü anneye yükleyip, onu ahlak öğretmeni olarak adlandırdıkları görülür. 1940'lı yılların filmlerinde ise "ayartıcı" kadın ile "ağır" kadın kutbu arasındaki karşıtığı barındıran annelik melodramları başlar (Akbulut, 2008, s. 82-83). Filmlerde kadına biçilen roller ile eril tahakküm tarafından topluma bir kadın profili çizildiği ortadadır. Bu durum, toplumların uluslaşma sürecinde yoğun olarak görülmekle birlikte, daha sonraki dönemde erilin izdüşümleri çerçevesinde filmlere yansımıştır. Türkiye'de de bunu görmek mümkündür.

Cumhuriyetin ilk yıllarında Halkevlerinin farklı saha ve biçimlerde faaliyet 
göstermelerinde -özellikle tiyatro aracılığıyla yapılmışıı çünkü sinema bu dönemde toplumda yaygınlaşmış bir eğlence aracı değildir- temel amacı ulus fikrinin yaygınlaştıııması ve insanların kendilerini bir ulusun parçası olarak göstermelerini sağlamaktır. Ancak bu iletimde diğer ulus pratiklerinde de gözlendiği gibi, üzerinde çok durulmayan ya da çoğu kez görmezden gelinen bir boyut daha vardır. O da ulus ve ulusçuluğun cinsiyetle ilişkisi ve özellikle de kadınlara bakışıdır. Ulus inşasının bir boyutu, inşacı aktörlerin kadınlara ve erkeklere çeşitli roller atfetmelerine ve onların toplum içindeki yerlerini ayrıntılı bir biçimde tasarlamalarıyla ilişkilidir. Bu inşa sürecinde dün ve gelecek, dostlar ve düşmanlar, hedefler ve ilkeler kapsamlı bir şekilde inşa edilirken, aynı zamanda kadınlığı ve erkekliğin inşası da söz konusudur. Bu anlamda ulusçuluk projeleri aynı zamanda birer toplumsal cinsiyet projeleridir (Dede, 2015, s. 260-261). O dönemde toplumun eğlence ve bilinçlendirme aracı olan tiyatroda toplumsal cinsiyet projesi olarak üç kadın tipi topluma yansıtılmıştır. Bunlardan ilk kadına yapılan övgüdür. Erkeklerin cephede bulunduğu dönemde kadınların gerek cephe gerisindeki desteklerini, gerekse toplumsal hayatın devamlıı̆ına sağladıkları katkıyı kutlamakta ve övmektedir. İkinci sunulan prototip ise, kadınların birer biyolojik üretici olarak konumlandırımasıdır. Biyolojik üreticilik vasfı, kadınlara bakışın merkezi bir öğesi olduğundan ulus inşa süreçlerinde kaçınılmaz olarak yer bulur. Ancak anneliğin önemi yalnız doğumdan ibaret kalmamakta, annenin aynı zamanda çocuğun ilk öğretmeni olması vasfı, nesillerin eğitimi bakımından da önemli görülmektedir. Üçüncü prototip ise, ulus inşasında kullanılan ideolojik söylemlerde sembolik bir yer tutmaktadır. Kadınları eski rejimde tamamen özel alan sıkışłıııdıkları ve burada da baskı altında oldukları, hukuken erkeklerle eşit olmadıkları, evliliklerinin gerçekleşmesi ve sonlanması başta olmak üzere medeni hukuk, miras hukuku ve siyasal hakları bakımında mağdur konumunda bulundukları, bu yöndeki eleştirilerin temel taşlarıdır. Buna bağlı olarak cumhuriyet iradesi, kadınlara haklarını sunuşunu ve özellikle de onları erkeklerle eşit kılma doğrultusunda getirdiği yasal düzenlemeleri sıkça vurgulayacaktır. Bu vurgu kadının eski ile yeni arasındaki farkı sergilemesinde bir göstergedir (Dede, 2015, s. 272-273).

Cumhuriyetin ilk yıllarında tiyatro aracılığı ile başlayan ve daha sonra sinema ile devam toplumu "bilinçlendirme" çalışmalarında kadının toplumsal cinsiyet kimliğinin inşası, eril tahakkümün denetlediği bir sistemde melodram filmler aracılığı ile yapılmıştır. Bu filmler, kadın-erkek ilişkilerindeki gerginlikleri giderme konusunda, 


\section{arts}

hem ataerkil kuralların geçerli olduğu dünyanın olağanlığı ve doğallığını kanıtlamaya çalışarak, hem de yaşam tarzının sivriliklerini törpüleyerek önemli bir işlev görür. Türk sineması da belli bir dönemde, kültürel bir biçim olarak popüler filmler aracılığıyla "kadın olma"nın anlamlarını üretmiş, Türkiye'deki ataerkil düzenin iktidar ilişkileri ve ideolojisinin gerekleri doğrultusunda kadın modelleri çizmiştir (Abisel, 1994, s. 126). Örneğin 1960'lı yılların Türk sinemasında iki kadın tipi çizilmiştir; "erkek gibi kadın" ile "hanım hanımcık kadın" imajlarıdır (Biryıldız, 1993, s. 14). Ancak dişi lumpenlerin abartılı erkek rollerini üstlenerek erkek dünyasına girebilmeleri için ödedikleri bedel ise; dilediğin kadar erkeksi tutumlar gösterebilirsin, hatta bu tutumları gösterdiğin ölçüde kahramanlığın pekişecektir ama toplumsal cinsiyet kimliği olarak, ev içinde, yatakta ve mutfakta kadın olmak koşuluyla, sevgililerin erkek olması koşuluyla ve çocuk doğurmak koşuluyladır (Soykan, 1993, s. 66). Bununla birlikte popüler filmler aracılığı ile Türk sineması kadına ilişkin kendi ideolojisini şöyle ortaya koymuştur: kadın karakterlerin başına gelenler -ister töreler, ister kötüler, ister kader yüzünden olsunçok korkunçtur; bu yüzden kadınlara acımamak elde değildir, ama işte kadını kadın yapan tam da budur; bütün korkunçluklara gerektiğinde boyun eğmeyi bilmesidir. Kadın eğer çok büyük bir yanlışlık yapmamışsa, sabrının, fedakârlığının ödülü olarak erkek karşısında küçük-duygusal-başarılar ve "evlilik tacı"nı kazanabilir. Fakat erkeğin temel mutsuzluk kaynağı olduğu zaman ise gerektiğinde ölerek cezalandırıması da mubahtır (Abisel, 1994, s. 127). Türk sinemasında bu filmler aracılığı ile erkeğin ideal kadın izdüşümleri perdeye yansıtılmış, bu ideal kadın izdüşümlerinin dışında hareket edenlere tecavüz edilerek, kötü kadın imajı yaftalayarak tehlikeli ve arzu edilen bir nesne haline dönüştürülmüştür. Örneğin Muhterem Nur sürekli olarak rolün gerektirdiği biçimde aldatılan, sömürülen ve öykünün sonunda barlara, pavyonlara düşen kadın türünü canlandıran bir oyuncudur (Öngören, 1982, s. 31).

Cinselliği geniş bir biçimde kullanan sinema, her dönem yarattığı cinsel nesneler, modalar ve akımlarla kadını arzu edilen cinsel hedefler haline getirmiştir (Dorsay, 2000, s. 97). Örneğin Türk sinemasında 1960'lı yıllarda stilize bir cinsellik perdeye hâkim olmuştur. Çolpan İlhan'ın hafif "nemfoman" sosyete kadını tipi, Leyla Sayar'ın Halit Refiğ veya Metin Erksan filmlerindeki çeşitli sapkın öğeler içeren ünlü sahneleri bu stilize cinselliğe örnek verilebilir (Dorsay, 2000, s. 216). Bununla birlikte kadın cinselliği Türk sinemasında oldukça istismar edilmiştir. Örneğin 1960'lı yıllarda cinsellik bazen melodram, bazen bir sosyal eleştiri filminin içinde dolaylı olarak, bazen 
de bir kadının güzelliğini sergilemek amacıyla kullanılmaktaydı. Çünkü bu dönemde, 1970'lerdeki gibi belli bir hedef kitle ve kitleye yönelmiş -pornografiye sapan- bir cinsellik yoktur ve furyaya dönüşen seks filmleri henüz moda olmamıştır. Toplum da sinemacılar da bu tür filmlere hazırlıklı olmadıklarından cinsellik biraz ilkel, biraz üstü kapalı biçimde verilmiştir (Soykan, 1993, s. 60). Örneğin Halit Refiğ'in Şehrazat - Dişi Örümcek filmindeki Leyla Sayar'ın çizdiği vamp karakteri, kimi zaman romantik, kimi zaman ölümü vurgulayan bir kadındır. Bu vamp kadınla Türk sinemasında cinsellik bir ölçüde kendini kabul ettirmiş, kadın vücudu ve çıplaklık yasallaşmıştır. İkinci derece rollerde görünen vamplar, soyunan, sevişen, striptiz yaparak seyirciyi etkileyen kadınların aksine başrol kadın oyuncuları, kötü kadın rollerine çıkmazlar, genelde namuslu ve masum kadınları canlandırılar, toplumdaki temel ahlak kurallarına ters düşmeden ve hatta bunları pekiştirerek "aile kadını" imajı ile özdeşleşmişlerdir (Soykan, 1993, s. 61). Bu dönem Türk sinemasında çıplaklık, sevişme ve diğer cinsellik öğelerini taşıyan sahneler çoğunlukla ilkel, kaba ve şiddetin etkisi olarak kendini göstermiştir. Birbirini seven iki insanın cinsel bakımdan seviştiği sahnelere rastlamak ya pek mümkün değildir ya da bu sahnelerde erkeğin kadını zorla alma ve bu sırada da kabaca davranma eğilimi ağır basmaktadır. Bunda Türk toplumunun ataerkil yapısında erkeğin böyle davranabileceği düşüncesi ve sevişme sırasında bile "erkekliğini kanıtlama" eğilimi vardır. Bununla birlikte 1960'lı yılların melodram filmlerinde tecavüz sahneleri de çoğunluktadır (Öngören, 1982, s. 70). Örneğin bu dönemde Metin Erksan'ın Kuyu filmi erkeğin zorbalığı ve cinsel tutkuları ile kadının edilgen ve bağımlı durumunu Türk toplumunun eril egemen kültürünün kırsal kesimdeki en tipik göstergesidir (Soykan, 1993, s. 56).

\section{FiLMLERIN ÇÖZÜMLENMESi}

\section{Acı Hayat - 1962 / Metin Erksan}

Konusu: Film, Mehmet (Ayhan Işık) ile Nermin'in (Türkan Şoray) umutsuz aşk hikâyesini anlatır. Kuaförde çalışan manikürcü Nermin ile tersanede çalışan kaynak işçisi Mehmet birbirlerine âşıktır ve evlilik için bütçelerine uygun bir ev arayışı içindedirler. Ancak istedikleri evi bir türlü bulamazlar ve Nermin evlilikle ilgili umudunu kaybeder. Nermin bir gün manikür için gittiği evde zengin bir sosyete kadının oğlu 


\section{arts}

olan Ender (Ekrem Bora) ile tanışır. Ender, Nermin'in peşini bırakmaz ve onunla ısrarlı bir şekilde evlenmek ister. Ender'in teklifi karşısında Nermin'in kafası karışır. Mehmet ile birlikte bütçelerine uygun bir ev bulamayan Nermin gecekondu yaşamından ve yoksulluktan kurtulmak için Ender'in teklifini kabul eder. Ancak Ender'in ailesi bu evliliğe karşı çıkar. Daha sonra Nermin, yaptığı seçimden dolayı pişmanlık duyar ve Mehmet'e geri dönmek ister. Fakat gururu kırlan Mehmet, hem Nermin'den, hem de Ender ve ailesinden intikam almak için planlar yapar.

\section{Filmde Kadının Toplumsal Cinsiyet Kimliğinin Inşası}

Eril egemen toplumda kadına biçilen rol melodram ağırlıklı filmlerde sıklıkla işlenir. Kadın aile hiyerarşisi içinde erilin tahakkümü altındadır. Ancak bunu sorgulayan toplumsal gerçekçi ama melodram özellikleri barındıran filmler de Türk sinemasında vardır. Metin Erksan'ın Acı Hayat filmi bu filmlerden bir tanesidir. Erksan, zengin oğlan fakir kız hikâyesini klasik Yeşilçam kalıplarının dışında gerçekçi bir şekilde anlatmıştır. Filme genel olarak baktığımız zaman umutsuz bir aşk hikâyesini anlatıyor gibi gözükse de, bu film sınıf atlamanın zengin biriyle evlenme gibi kolay olacağını pekiştiren popüler melodram filmlerin aksine gerçekçi bir yaklaşımla sınıfsal farklııkları perdeye yansıtmıştır.

Filmde kadının Türk toplumunda konumunu anlatan önemli sahnelerde biri, Ender'in Nermin'in peşine ısrarcı bir şekilde takıldığı sahnedir. Ender ısrarcı bir şekilde Nermin'e güzelliğine vurulduğunu anlatır. Burada eril tahakküm, güzelsen erilin gözetiminde ve takibindesin mesajını verir. Filmde kadının bedeni cinsel olarak kullanılmaktadır. Diğer bir ifadeyle Nermin' in bedeni, Ender'in habitusu içinde baştan çıkarıcı ve arzu edilen cinsel pratiklerde bulunmaktadır. Ender'in habitusunda bu konumda bulunan Nermin'in istismar edilmesi de şaşırtıcı değildir.

Yine önemli sahnelerden biri ise, Mehmet ve Nermin'in minibüste tartıştıkları sahnedir. Evlendikten sonra Nermin'in çalışmamasını isteyen Mehmet'in tartıştıkları bu sahnede eril toplum yapısının kadına toplumda biçtiği rolü açıklıkla görebiliriz. Kadın evlendikten sonra çalışamaz, evinin kadınıdır ve çocukları büyütmekle görevlidir. Nermin'in Mehmet'teki izdüşümü evlenip eş ve anne olmall, çocukların bakımını üstlenmeli ve namuslu bir kadın bedenine sahip olarak erkeğin soyunun 
devamını sağlamalıdır.

Filmde hem Nermin'in, hem de Filiz'in (Nebahat Çehre) Ender ve Mehmet tarafından infial edilmesi, Türkiye'de bütün toplumsal katmanlarında kadının "cinsel saflğı"nın erkekler tarafından desteklendiğini göstermektedir. Bununla birlikte Nermin'in Ender tarafında infial edildikten sonra, "başkalarının ne diyeceği" söylemi üzerinde Ender'e yaklaşması, eril tahakkümün kadın bedenlerini güvensizlik konumunda tutabilmelerinin sürekliliğine bağlıdır. Ya da Nermin'in Ender tarafından taciz edildikten sonra kendi bedensel varlığını korumak için Mehmet ile bir an önce evlenmek istemesi de, bedensel güvensizlik konumunun eril iktidar tarafından sürekliliğinin sağlandığının en büyük göstergesidir. Nermin'in Ender tarafından taciz ve infial edilmesi korkunçtur; Nermin'e acımak içten değildir. Ancak Nermin'in Nermin yapan işte tam da budur; bütün korkunçluklara gerektiğinde boyun eğmesini bilmiştir. Fakat bütün bu korkunçluklara boyun eğmesi ve fedakârlığının ödülü olan "evlilik tacı"nı kazanamamıştır. Bununla birlikte Mehmet'in temel mutsuzluk kaynağı olduğu için intihara sürüklenmiştir.

\section{Kırık Hayatlar - 1965 / Halit Refiğ}

Konusu: Film karısını aldatan Doktor Ömer'in (Cüneył Arkın) hikâyesini anlatır. Doktor Ömer ve karısı Perihan (Belgin Doruk) iki çocuklu modern bir çekirdek ailedir. Yeni bir mahalleye taşınmışlardır. Bu mahalle zengin komşularının olduğu bir muhittir. Bir gün karı koca, mahalle komşularının düzenledikleri bir partiye katııılar. Ömer, partide uzun zamandır görmediği eski arkadaşı Bekir ile karşıllşır. Bekir, partide arkadaşı Doktor Ömer'i yakın arkadaşlarından Sahire hanım ve kızları ile tanıştııı. Bir gün Sahire hanımın rahatsızığı nedeniyle evlerine giden Doktor Ömer, Sahire Hanım'ın kızı Gülşen (Nebahat Çehre) ile kapıda karşılaşır ve aralarında bir yakınlaşma başlar. Bu yakınlaşma ile Doktor Ömer'in karısı Perihan ile arasına soğukluk girmesine ve ailenin parçalanmasına yol açar.

\section{Filmde Kadının Toplumsal Cinsiyet Kimliğinin İşası}

Halit Ziya Uşaklıgil'in romanından aynı adla uyarlanan filmde modern çekirdek 


\section{arts}

bir aileden bahsedilmektedir. Baba, anne ve iki kız çocuktan oluşan bu aile, Doktor Ömer'in mesleğinin getirisiyle sınıf atlamıştır. Bu modern ailede roller dağıtılmışıı; baba Doktor Ömer evi geçindirmek için çalışmakta, anne Perihan ise ev işleriyle ilgilenmekte ve çocuklarının bakımlarını üstlenmektedir. Perihan'a bu toplumda çizilen rol, hem erkeğin cinsel partneri, hem de erkeğin soyunun devamını sağlayan kişi olmaktır. Bununla birlikte, bu modern aile modelinde Perihan'a biçilen rol, ulusçuluk projesinde kadının bir biyolojik üretici olarak konumlandırımasının yanı sıra, çocuğun ilk öğretmeni ve nesillerin eğitimi bakımı görevlerinin anneye verilmesinden kaynaklanmaktadır.

Doktor Ömer bir sahnede Perihan'a, "Siz kadınlar kalbinizde sizi kemirecek bir kurda her zaman muhtaçsınız. Bir derdiniz yokken bile yine sızlanacak bir şey bulursunuz" diye veryansın eder. Burada Doktor Ömer, Perihan'ı ikincil bir konuma iterek, kadını zayıf ve kırılgan göstermektedir.

Bir başka sahnede ise, Perihan'ın asker kökenli babasının "Medeni kanun olmasaydı, ben size sorardım" diyerek cumhuriyet iradesinin ya da ideolojik söyleminde kadına sembolik bir yer verdiğini çıkarabiliriz. Burada verilen sembolik değer ile kadının eski rejimde özel alana sıkışmış bir hayatının olduğu, erkeklerle eşit hakka sahip olmadığı ve evlilik başta olmak üzere hukuki ve siyasal haklardan mağdur olduğu ideolojik söylemi pekiştirilmektedir. Bunun yanı sıra, Doktor Ömer'in Perihan'ı aldatması üzerine, Perihan'ın babasının son sahnede "Karısının üzerine her gül koklayanın kızı ölse, en başta sen yaşamazdın" diyerek hem kadını bir arzu nesnesi olarak konumlandırmakta, hem de cumhuriyetin kadına medeni hukukla eşit haklar getirmesine rağmen, bu söylemin sembolik be içi boş olduğunu işaret etmektedir.

Filmde kadının toplumsal cinsiyet kimliğinin konumu veya eril tahakkümün karşısında itaatkâr olarak konumlandırıması, ailenin hizmetçisi olan Fatma'nın evin diğer hizmetçisi Hatice'nin eşinden gördüğü şiddet karşısında söylediği sözlerden Çıkarabiliriz: "Erkektir döver, kol kırılır yen içinde kalır" ya da "Kadın kısmı katlanacak kocasının çilesine. Kitap böyle yazıyor. Katlanamadımı bana döner Allah göstermesin. Yaşlıı̆ında el kapılarında sürünür. Ah gençlik, insan bunu vaktiyle bilse."

Filmde aynı zamanda Perihan' a biçilen "ağır" kadın rolü ile annelik misyonu 


\section{$\operatorname{arts}=$}

yüklenirken, "ayartıcı" kadın rolü ise Gülşen'e verilmiştir. Burada "ayartıcı" kadın rolünde bulunan Gülşen, modern aile yapısını bozan tehlikeli bir kişiliktir ve bu kişilik tehlike arz ettiği için bir şekilde eril tahakkümün kurallarını belirlediği habitustan uzaklaştırıır.

\section{SONUÇ}

Hangi toplumsal sistemde olursa olsun, erkeğin oluşturduğu habitusta kadın ikincil bir konumdadır. Bu habitusta kadının toplumsal cinsiyet kimliği erkeğin ön gördüğü şekilde inşa edilmektedir. Patriarkal toplumlarda kadın erkeğin cinsel partneri, soyunun devamını sağlayan biyolojik üretici, çocukların bakımını ve yetişmesini üstlenen kişidir ve ailenin de itaatkâr olan en önemli bileşenidir. Aynı zamanda bu toplumda kadın, "ayartıcı", "kışkırtıcı" ve "tehlikeli" bir kişilik olarak da kodlanmaktadır. Namus bağlamında kadınların bedenleri gözetlenerek ve bedensel güvensizlik konumunda tutularak sembolik mallar piyasasının nesneleri haline getirilmektedir.

Eril tahakkümün kurduğu habitusta filmler, kadının toplumsal cinsiyet kimliğinin inşasını toplumda pekiştirilmesinde önemli bir rol oynamaktadır. Türk sinemasında ise, ister toplumsal gerçekçi olsun, ister melodram ağırlıklı popüler filmlerde olsun kadın karakterlerin başına türlü şeyler getirilerek, ya erilin tahakkümüne itaat etmesi (evlenerek ya da onun koruması altında yaşamasını kabul etmesi koşuluyla), ya da bir arzu nesnesi olarak tekinsiz bir konuma itilmesi sağlanır. Erilin tahakkümü altına girmeyen kadın ya bu toplumda barınamaz ve uzaklaşır, ya da intihar ederek ölür veya ölümle cezalandırıır. Örneğin Acı Hayat filminde erilin tahakkümüne girmeye Nermin intihar etmeye yönlendirilirken, Kırık Hayatlar filminde kendi arzuları peşinde koşan ve Doktor Ömer ile yasak aşk yaşayan Gülşen, bulunduğu ülkeyi terk etmek zorunda kalır. 


\section{arts}

\section{KAYNAKÇA}

Abisel, N. (1994). Türk Sineması Üzerine Yazılar (1. Baskı). Ankara: İmge Kitabevi Yayınları.

Akbulut, H. (2008). Kadına Melodram Yakışır: Türk Melodram Sinemasında Kadı Imgeleri (1. Baskı). İstanbul: Bağlam Yayınları.

Aylin, N. (2015). Kadın Bedeni ve Toplumsal İzdüşümleri: Sosyolojik Bir Bakış. F. Z. Fidan ve D. Alptekin (Ed.), Kadın Bedeni ve Istismarı. İstanbul: Opsiyon Yayınları.

Biryıldız, E. (1993). Şoför Nebahat mı olalım, Küçük Hanımefendi mi? . Marmara Illetişim Fakültesi Dergisi, 4, 5-18.

Bourdieu, P. (2001). Masculine Domination. California:.Stanford University Press.

Dede, K. (2015). Erkek Doğmadık Diye Yurdumuza Küs müyüz? Halkevi Sahnelerinden Kadın Kesitleri. S. Coşar ve A. Özmen (Ed.), Milliyetçilik ve Toplumsal Cinsiyet: Edebiyat, Medya, Siyaset. İstanbul: İletişim Yayınları.

Dorsay, A. (2000). Sinema ve Kadın (1. Baskı). İstanbul. Remzi Kitabevi.

Giddens, A. (1999). Toplumun Kuruluşu (Çev. H. Özel). Ankara: Bilim Sanat Yayınları.

Küntay, E. (2010). Bedene Şiddet -Özbenlik Değerlendirmeleri Toplumbilimsel Bir Analiz. Y. Inceoğlu ve A. Kar (Ed.), Kadın ve Bedeni. İstanbul: Ayrıntı Yayınları.

Özgüç, A. (1994). Türk Sinemasında Cinselliğin Tarihi (1. Baskı). İstanbul: Antrakt Yayınları.

Öngören, M. T. (1982). Sinemada Kadın ve Cinsellik Sömürüsü (1. Baskı). Ankara: Dayanışma Yayınları.

Özbudun, S. (2015). Dinler, İslam ve Kadın Bedeni. F. Z. Fidan ve D. Alptekin (Ed.), Kadın Bedeni ve İstismarı. İstanbul: Opsiyon Yayınları.

Ryan, M. ve Kellner, D. (1997). Politik Kamera: Çağdaş Hollywood Sinemasının 
İdeolojisi ve Politikası (Çev. E. Özsayar). İstanbul: Ayrıntı Yayınları.

Sancar, S. (2009). Erkeklik: Imkânsız iktidar: Ailede, Piyasada ve Sokakta Erkekler (1. Baskı). İstanbul: Metis Yayınları.

Soykan, F. (1993). Türk Sinemasında Kadın 1920-1990 (1. Baskı). İzmir: Altındağ Matbaacilik.

Tahincioğlu, A. N. Y. (2011). Namusun Halleri (1. Baskı). İstanbul: Positiga Yayınları.

Türk, H. B. (2008). Eril Tahakkümü Yeniden Düşünmek: Erkeklik Çalışmaları İçin Bir İmkân Olarak Pierre Bourdieu. Toplum ve Bilim Dergisi, 112, 119-147.

Weeks, S. (2016). Bir Kavramın Anatomisi Cinsellik (Çev. İ. Güzel). İstanbul: Everest Yayınları. 